\title{
Analyzing Consumers' Awareness towards CSR, Focusing on Environmental Management
}

\author{
Eleni Sardianou \\ Department of Home Economics and Ecology \\ Graduate Program of Sustainable Development \\ School of Environment, Geography and Applied Economics, Harokopio University, Greece \\ E-mail: esardianou@hua.gr \\ Athanasia Stauropoulou \\ Department of Home Economics and Ecology \\ Graduate Program of Sustainable Development \\ School of Environment, Geography and Applied Economics, Harokopio University, Greece \\ Ioannis Kostakis \\ Department of Home Economics and Ecology \\ Graduate Program of Sustainable Development \\ School of Environment, Geography and Applied Economics, Harokopio University, Greece
}

Received: March 28, 2017 Accepted: April 30, 2017

doi:10.5296/emsd.v6i2.10983ＵRL: https://doi.org/10.5296/emsd.v6i2.10983

\begin{abstract}
The deployment of environmental friendly business practices is strongly related to the principles of the sustainable development. The customers are an important stakeholder group that appears to be sensitive to the corporate social responsibility (CSR) actions of a company. The environmental dimension is increasingly being included as a pillar of a company's CSR plan. The aim of this study is to examine the determinants that affect consumers' awareness of the environmental dimension of a company's CSR plan, called hereafter corporate environmental responsible (CER) activities. Results suggest that consumers' awareness
\end{abstract}


towards CER practices is differentiated regarding their demographic profile. Highly educated and middle aged consumers are more sensitive to corporate environmental responsible practices. The income of a consumer is not a statistically significant factor though regarding their awareness of environmentally responsible firms.

Keywords: Consumer, Awareness, CSR, Environmental management

\section{Introduction}

The deployment of environmental friendly business practices is strongly related to the principles of sustainable development. Customers, one of the most important stakeholder groups of a firm, are sensitive to corporate social responsibility (CSR) actions (Mohr et al., 2001; Rahim et al., 2011; Grimmer \& Bingham, 2013). There is a wealth of research attempting to define what it means for a company to adopt CSR actions. In particular, the most widespread definition of corporate social responsibility is that of Carroll's pyramid (1991). Carroll (1991) stated that social responsibility of businesses encompasses four dimensions in the following decreasing order of importance: economic, legal, ethical and philanthropic responsibilities. An expansion of Carroll's concept that captures the environmental dimension of a company's social responsibility is the one developed by the European Commission (2001; 2011). According to the European Commission (2001) "being socially responsible means not only fulfilling legal expectations, but also going beyond compliance and investing "more" into human capital, the environment and the relations with stakeholders"(page 6). The environmental dimension is increasingly being included as a pillar of a company's CSR plan (Montiel, 2008). In the renewed European Union strategy for corporate social responsibility, CSR is defined as "a process for firms to integrate social, environmental, ethical and human rights concerns into their operations and core strategy" (European Commission, 2011, page 6). Some studies have examined the environmental dimension of the CSR concept (Mohr et al., 2001; Rahim et al., 2011; Grimmer and Bingham, 2013). A subcategory of the broader concept of Corporate Social Responsibility (CSR) is Corporate Environmental Responsibility (CER). Mazurkiewicz (2004) recognized CER as the commitment of business to take the environment into account in decision-making processes and involves measuring and auditing. Gunningham (2009, page 215) defined CER as "practices that benefit the environment (or mitigate the adverse impact of business on the environment) that go beyond those that companies are legally obliged to carry out". Bisschop (2010, page 351) summarized CER "as the responsibility of business towards various stakeholders to take into account the environmental consequences of business activities and the longer-term environmental needs in order to avoid compromising the sustainability of future generations. Environmental practices may include green technologies, recycling programs, carbon emissions reduction programs, waste management, auditing, green technologies, etc. (Mazurkiewicz, 2004; Montiel, 2008; Gunningham, 2009; Dögl \& Behnam, 2014). Several empirical studies have been conducted to measure consumers' awareness toward a company's CSR actions and stressed the importance of communication strategies for consumer decions making process (Singh et al., 2008; Lee \& Shin, 2010; Maignan, 2001; Mohr et al., 2001; Rahim et al., 2011; Gupta \& Hodges, 2012). 
Taking all the above mentioned into consideration, this study contributes to our knowledge of consumers' awareness towards firms' corporate environmental responsibility, providing empirical evidence from Greek consumers. Unlike previous studies, the objective of our research is to examine the demographic determinants that affect consumers' awareness of a company's CER actions. According to the authors' knowledge, this current research differs from prior studies in this field, as it analyzes the profile of consumers that are aware of companies that adopt CER activities. We focus on firms' CER because the environment was found to be the most important concern for stakeholders in a company's CSR efforts (Kassinis \& Vafeas, 2006; Welford et al., 2007), Companies seek to implement CER practices in order to meet the growing stakeholders' demand for environmental responsibility (Dögl \& Behnam, 2014). Awareness of the company's activities is a major target of a company's communication strategy since stakeholders might use the information to assist their decision-making process (Bernam et al, 1999). Studies highlighted the need for more communication of company's CSR practices to strengthen consumers' decision making process (Maignan, 2001; Mohr et al., 2001; Singh et al., 2008; Lee \& Shin, 2010; Rahim et al., 2011; Gupta \& Hodges, 2012). Consumers are not well aware of environmental activities adopted by them (Singh et al., 2008; Öberseder et al., 2013). Thus, we study consumers because we expected that by profiling consumers' awareness of the environmental dimensions of a CSR (called CER), companies can develop their marketing campaigns appropriately and obtain competitive advantage in the marketplace.

The structure of the paper is as follows. The next section reviews the existing literature. The successive two sections present the data and the adopted methodology of the analysis. Subsequently the derived empirical results are presented and discussed. The last section concludes the paper and present policy implications of the analysis.

\section{Literature Review}

There is a wealth of research attempting to define what it means for a company to be socially responsible (see for e.g. Carroll, 1991, European Commission, 2001; 2011). Within this context studies support that CSR has its theoretical roots in the stakeholder theory (Campbell, 2007; O’Connor \& Spangenberg, 2008; Asif et al., 2013; Dögl \& Behnam, 2014; Lu \& Abeysekera, 2014). New challenges for businesses in the reformed global marketplace have been created due to growing competition which is mainly based on efficiency, cost reduction and consumers' satisfaction (Asif et al., 2013; O'Connor \& Spangenberg, 2008). CSR and CER are two of the most important features that characterize a "good" company nowadays. In particular, CSR is marked as a form of investment intended to maximize a firms' profits. This can be achieved because the risk and cost of CSR involvement is much lower than its less social responsible counterpart (Cruz, 2013; Lu \& Abeysekera, 2014). However, a contradistinction of research is focused on the issue how CSR can be effectively integrated within existing business processes (Asif et al., 2013). Campbell (2007) indicates that a business should not follow a strategy that can harm its key stakeholders and if it occurs, the business has to rectify it whenever the harm is discovered. Integration of CSR actions in the operation of a business requires the knowledge of infrastructure to match the requirements of stakeholders in a more sustainable manner. Within this context, Mohr et al. (2001) and Rahim 
et al. (2011) mention that corporate socially responsible behaviour includes a broad array of actions aimed at minimizing damage to the environment, called CER. Consumers' perception of the environmental performance of companies is supposed to positively influence their purchasing behaviour (Grimmer \& Bingham, 2013). Companies focus on their primary ${ }^{1}$ stakeholders, however consumers are not well aware of environmental activities adopted by them (Singh et al., 2008; Öberseder et al., 2013).

The main processes of integration of CSR actions are the "top-down integration" and the bottom-up integration". The first perspective's starting point is the strategic direction which includes environmental scanning. On the other hand, the "bottom-up" perspective requires for a business to look beyond internal processes and focus on the broader impact on the communities (Asif et al., 2013). Similarly, the most successful companies are those that have incorporated the three sustainability dimensions of economic, ecological-environmental and equity-social sustainability in their business practices (Amini \& Bienstock, 2014). Nevertheless, there seems to be a lack of knowledge regarding CSR development in Europe as indicated by Rananger \& Zobel (2014). The main difficulty expressed here is the manner in which CSR has been addressed in the business sector. In addition, there is a lot of research that supports the positive causality of CSR and financial performance in a business sector with its relationship not being static but changing over time (Ballester, 2014; Lu et al., 2014).

Human values are an additional important driver of the behaviour of companies (Sidiropoulos, 2013). Several empirical studies have been conducted to measure consumers' awareness toward a company's CSR actions (Gupta \& Hodges, 2012; Lee \& Shin, 2010; Maignan, 2001; Mohr et al., 2001; Rahim et al., 2011; Singh et al., 2008). All these studies highlighted the need for more communication of their CSR practices. In particular, consumers declared that they had a difficulty to understand the concept of CSR (Rahim et al., 2011; Singh et al., 2008) and the lack or low level of awareness is confirmed to be a major barrier in acquiring a positive attitude. Subsequently this will influence them in choosing for a socially responsible company (Gupta \& Hodges, 2012; Lee \& Shin, 2010; Maignan, 2001). Lack of awareness is attributed mainly to difficulties in obtaining information on the CSR actions of a firm (Mohr et al., 2001), a raised awareness could lead to a higher level of purchase intention (Maignan, 2001). As Bhattacharya \& Sen (2004) confirmed, consumers evaluated a company more positively when provided with information about its CSR record.

The bulk of the research attests that there is a positive influence of CSR actions on the financial performance of the companies. In this context, most of the studies focused on the fact that companies which publicize their socially responsible actions can positively impact consumers' purchase behaviour (Groza et al., 2011; Marquina \& Morales, 2008; Rahim et al., 2011; Sen \& Bhattacharya, 2001; Tian et al., 2011; Wigley, 2008). However, the influence of CSR on the decision processes of consumers is complex and differentiates

\footnotetext{
1 A primary stakeholder is defined an individual or group who can affect or be affected by the actions of a business, such as the distribution of a product or a change to a service agreement. Primary stakeholders include for example customers, employees, suppliers, etc. (available at: http://www.businessdictionary.com/definition/primary-stakeholder.html).
} 
between intention and actual behaviour. More specifically, Tian et al. (2011) found that awareness of socially responsible actions only had a significant positive effect on the purchase intention of consumers. Mohr et al. (2001) confirmed that only a limited segment of consumers considered in their purchasing choice whether the product was made by a socially responsible company. Similarly, Gupta \& Hodges (2012) concluded that price and quality of the product was a much more important purchasing criterion. Finally, Papadopoulos et al. (2011) indicated that Greek consumers should be convinced about the sincerity of the CSR policies in order to influence their purchasing behaviour. CSR practises thus may indirectly affect the company's financial performance (Wigley, 2008). Studies on consumer behaviour suggested that CSR activities generated a competitive advantage to the company, through brand loyalty and differentiation (Luo \& Bhattacharya, 2006; Marquina \& Morales, 2008; Stanaland et al., 2011), influenced corporate reputation, trust, through advertising (Bhattacharya \& Malani, 2013; Öberseder et al, 2013) and therefore consequently benefit product sales (Bhattacharya \& Malani, 2013).

Consumers believed that rewarding companies that adopt CSR activities could be a motivating factor for other companies to be more socially responsible (Gupta \& Hodges, 2012), confirming they were more willing to purchase products from companies that care about society (Grimmer \& Bingham, 2013; Sen \& Bhattacharya, 2001) and even willing to pay more for them (Gupta \& Hodges, 2012). However, Bhattacharya \& Malani (2013) concluded that only a minority of the respondents were inclined to pay higher prices for products of socially responsible companies. In the same context, Gupta \& Hodges (2012) pointed out that although consumers were willing to pay more, they disagreed about the amount and considered it not right for them to pay for CSR activities. It is estimated that if the price and the quality of two products were the same, consumers would buy from the company that acts in an ethical and socially responsible manner (Maignan, 2001; Singh et al., 2008). However, as Green \& Peloza (2014) concluded, the size of the company also affects consumer's trust in its CSR actions.

Limited studies have been conducted on the demographic characteristics of consumers who respond positively to CSR activities. Results indicated that women, higher-education, and higher-income groups are more supportive of company's socially responsible actions (Youn \& Kim, 2008). Carrigan \& Attalla (2011) found that older consumers are more likely to take ethical issues into account when purchasing products, whereas Tian et al. (2011) concluded that consumers with a middle level of income and age would be more supportive of a firm's CSR practices.

\section{Data and Methodology}

This research presents insights into some of the determinants that affect consumers' awareness towards CSR, focusing on CER actions. Data for the current research were obtained from a random sample of Greek consumers. Athens is the capital of Greece where productive business activity is concentrated. The survey took place in the five shopping malls in the area of Athens, using an anonymous structured questionnaire. As a prerequisite, the respondents were above 18 years old and an income earner. The sampled consumers at each 
mall were chosen following systematic sample technique. In particular, the researcher chose a consumer entering the mall at random, and choices thereafter are equals intervals. According to this method, every fifth consumer entering the mall was interviewed until the number of interviews stipulated for that mall was completed. In order to collect a more representative sample, including multiple segments of the shopping population, this survey was conducted during both weekends and weekdays from 9:00 a.m. to 9:00 p.m. In total, 500 interviewers were conducted (100 per mall) and a total of 464 questionnaires were fully filled in. The previously mentioned sampling approach was applied to ensure a representative sample and taking into consideration the restrictions of the research framework, as well as the costs of money and time (Schatzman \& Strauss, 1973; Miles \& Huberman, 1994). The questionnaire consisted of two sections: The first section included closed type questions on demographic and economic characteristics of the consumers such as gender, age, educational background and monthly private income. In the second section, consumers were asked to describe their attitudes towards firms that adopt CSR and CER actions. Annex 1, presents the questionnaire used in the survey.

Empirical results are based on the estimation of logistic regression model. Logistic regression is used for predicting the probability of an event occurring by fitting data to a logit function. In our case, under the binary logistic model, the estimated value of the dependent variable is interpreted as the probability that a consumer is aware of a socially responsible company targeting environmental protection, as identified by the values of the explanatory independent variables. Therefore, in the empirical study, we employed the following expanded specification for a consumer's awareness of a company's socially responsible activities targeting environmental protection:

$$
\begin{aligned}
\operatorname{Logit}[\operatorname{Pr}(Y=1)] & =\beta_{o}+\beta_{1} \text { gender }_{i}+\beta_{2} \text { age }_{i}+\beta_{3} \text { age }_{i}+\beta_{4} \text { education }_{i}+\beta_{5} \text { income }_{i}+\beta_{6} \text { envir }_{i} \\
& +\beta_{7} \text { ics }_{i}+\varepsilon_{i}
\end{aligned}
$$

where $\mathrm{Y}$ is a binary variable indicating whether the consumer is aware of a company that adopts CER activities or not; specifically, the variable takes the value 1 when the consumer is aware of corporate environmental responsible activities and zero otherwise. Gender ${ }_{i}$ is a dummy variable accounting for 1 if the respondent is female and zero if male; age $e_{i}$ is the consumer's age; age $2_{i}$ is the square of the consumer's age; education is a dummy variable accounting for 1 if the respondent has completed graduate studies and zero otherwise; income $_{i}$ is the consumer's monthly private income in euros; envr $r_{i}$ is a dummy variable accounting for 1 if the respondent participates in environmental friendly actions; icsr $_{i}$ is a dummy variable accounting for 1 if the consumer has previously sought information on CSR dimensions and $\varepsilon_{i}$ is disturbance term. The empirical results from the estimation of Eq. (1) are presented in Table 1 in the next section of this study. Finally, using the following formula we are able to estimate the maximum age of consumers' awareness.

$$
\frac{\vartheta\left(b_{1} " A G E^{\prime \prime}+b_{2} " A G E 2^{\prime \prime}\right)}{\vartheta^{\prime \prime} \mathrm{A} G E^{\prime \prime}}=b_{1}+2 b_{2} " A G E^{\prime \prime}=0
$$




\section{Results}

In this section we present the results of the statistical and econometric analyses to estimate the determinants that affect consumers' attitudes toward corporate environmental friendly practices. From the sample of 464 consumers, $60.1 \%$ were women and $39.9 \%$ men. Most consumers had completed secondary education $(45.7 \%), 33 \%$ were university-educated and $16.8 \%$ had a master degree. Most respondents were between the ages of 41 and 50 years (49.5\%); $22.8 \%$ were between 18 and 25 years, $15.5 \%$ between 26 and 40 years and the rest above 50 years $^{2} .42 .0 \%$ of consumers were married. The consumers' average monthly private, non-property-related, income was $€ 740.00$. The income of $25.0 \%$ of consumers varied between $€ 750$ and $€ 1.000$ and $33.6 \%$ of consumers' declared income no higher than $€ 500$. However, $14.9 \%$ of consumers declared having an income above $€ 1250^{3} .47 .6 \%$ of the respondents reported that they were aware of socially responsible enterprises that operate in Greece and $35.1 \%$ could name a socially responsible company aiming at environmental friendly practices. ${ }^{4}$ From the sample of consumers in question, $21.3 \%$ had previously sought information on CSR dimensions. The majority of the respondents (53.9\%) participated in environmental friendly actions (such as recycling, waste management, eco-driving, reforestation, energy saving, etc. ${ }^{5}$ ) and $70.9 \%$ strongly believed that companies should adopt CER practices to minimize the environmental damage they cause.

Several interesting results were obtained from the empirical estimation of Eq. (1). Table 1 presents the results of the fitted binary logistic model with respect to consumer's awareness of a company's socially responsible activities focusing on environmental protection.

From Table 1 can be concluded that the variable "income" is statistically insignificant. Thus, consumers' income does not affect their awareness towards firms' CER actions. Contrary, the variable "age" is statistically significant at a $1 \%$ level. In particular, the coefficient of "age" is 0.16 and the relative risk of this particular variable is 1.174 , which implies that the corresponding percentage change is 0.174 . Thus in relation to age the odds of consumers' awareness toward a company's environmental responsible activities increase by 17.4 per cent, ceteris paribus. This means that as age of the respondent increases by one year the probability of awareness of CER activities increases by $17.4 \%$. Applying the formula (2), it follows that consumers' awareness of corporate environmental responsible actions reaching a maximum at 40 years of age. A similar result was reported by Tian et al. (2011). This result may imply that middle-aged persons are more likely to take environmental issues into account when purchasing products. Concerning the educational level, the result implies that the corresponding percentage change is 0.934 . This means that in relation to highly educated groups of consumers the odds of consumer awareness to CSR actions increases by almost 0.934 per cent while all other remain fixed. "Gender" results imply that women have an increased probability of almost $27.1 \%$ over men to be aware of companies that adopt

\footnotetext{
2 Open ended question. Percentages are grouped for better presentation within manuscript.

3 Open ended question. Percentages are grouped for better presentation within manuscript.

${ }^{4}$ The respondents that gave a positive answer regarding CSR and CER awareness also named a company that adopt similar practices.

5 It is expected that consumers reporting a general eco-friendly to be aware to firms' corporate environmental responsible actions than others.
} 
environmental responsible activities, ceteris paribus. These results are in line with those by Youn and Kim (2008) whose research indicates that women and higher-education groups are more supportive of CSR actions. Thus, companies should focus their communication strategies for the adopted CER activities to men and less educated persons so as to gain a competitive advantage to market place. As expected, the odds of consumers' awareness of environmental friendly companies increase by 0.284 and 2.525 in relation to consumers' general eco-friendly attitudes and consumers' prior knowledge about CSR dimensions, respectively. Both, "envir" and "icsr" are statistical significant at a $1 \%$ level. Thus, it is confirmed that CER has a clear connection with CSR, because it indicates its environmental pillar.

The Nagelkerke $\mathrm{R}$ square which is a measure of predictability of the proposed model is equal to 0.207 . The $\log$ likelihood statistic is quite high, rejecting the null hypothesis and concluding that at least one of the estimated coefficients is different from zero. Finally, the Hosmer - Lemeshow goodness of fit test (HL test) returned a chi-square value equal to 4.12 and a p-value equal to $0.721(>0.05)$. With a p-value greater than 0.05 , HL test indicates that our model fits the data well.

Table 1. Estimated binary logistic regression of consumer's awareness of a company's environmental responsible activities (yes: 1 no: 0 )

\begin{tabular}{|l|l|l|l|}
\hline Independent variables & Estimated Coefficients & Odds Ratio & $\mathrm{e}^{\beta} \mathrm{i}-1$ \\
\hline Constant & $4.62^{* * *}(4.24)$ & - & - \\
\hline gender & $0.24 * *(2.10)$ & 1.271 & 0.271 \\
\hline age & $0.16^{* * *}(2.77)$ & 1.174 & 0.174 \\
\hline age2 & $-0.002^{* * *}(-2.72)$ & 0.998 & -0.002 \\
\hline education & $0.66^{* * *}(2.83)$ & 1.934 & 0.934 \\
\hline income & $0.26(0.23)$ & 1.297 & 0.297 \\
\hline envir & $0.25^{* * *}(2.70)$ & 1.284 & 0.284 \\
\hline icsr & $1.26^{* * *}(5.01)$ & 3.539 & 2.539 \\
\hline Log likelihood & -260.821 & & \\
\cline { 1 - 2 } Nagelkerke $\mathrm{R}^{2}$ & 0.207 & & \\
\cline { 1 - 2 } Hosmer and Lemeshow & $4.12(0.721)$ & & \\
\hline
\end{tabular}

Note: $* * *, * *$ represent levels of significance at $1 \%$ and $5 \%$, respectively. $\mathrm{Z}$ statistics are presented in parentheses.

\section{Conclusion}

This paper has focused on providing insights into which factors affect consumers' awareness towards companies that adopt socially responsible activities aimed at environmental protection in Athens, Greece. For this purpose logistic regression model was estimated to identify the socioeconomic profile of the consumers that are aware of environmental responsible companies. The empirical results suggest that middle-aged people and women are more likely than others to be aware of a company's CSR actions targeting environmental dimensions, named for the purpose of the study CER actions. Further, it is estimated that 
income is not a predicted variable of awareness of corporate environmental friendly strategies. As consumers pay attention to companies' environmental strategies, more companies would be motivated to adopt a corporate environmental friendly image to gain competitive advantage and try more to satisfy the requests of their customers concerning better environmental performance. In this context, profiling customer groups would have multiple useful economic and environmental policy implications for firms' strategic plan.

A number of limitations of the current study can be noted, as well as some directions for future research. First, the sectional nature of this study might affect the interpretation of our empirical results. The analysis is based solely on self-reported intentions on the part of consumers without being able to verify their claims, regarding corporate environmental responsible actions adopted by firms. Nonetheless this is something common in all types of survey-based researches. Second, the study is focused on analyzing consumers' awareness towards firms' CER, without being able to examine purchasing preferences from environmental responsible firms. An understanding of consumer purchasing choices of CER at the firm level is important in the development and implementation of successful CER programs and enhancement of sustainability, since consumers buying in the midst of economic crisis products may not have as a market criterion the environmental practices of businesses but the cost. Thus, it is suggested for future studies to empirically explore consumers' awareness-buying outcome towards corporate environmental responsible firms, as this was not the scope of this current research. Future research on this topic, based on different time and countries are highly recommended. Finally, it would be important for policy makers to examine the reasons behind the managerial decisions not to adopt CER activities, so as to formulate effective motives to boost companies' environmental performance.

\section{Acknowledgements}

The authors would like to thank the Editor and the three anonymous reviewers for their insightful and constructive comments from which the present paper greatly improved. Any remaining errors or deficiencies are solely the authors' responsibility.

\section{References}

Amini, M., \& Bienstock, C. C. (2014). Corporate sustainability: an integrative definition and framework to evaluate corporate practice and guide academic research. Journal of Cleaner Production, 76, 12-19. https://doi.org/10.1016/j.jclepro.2014.02.016

Asif, M., Searcy, C., Zutshi, A., \& Fisscher, O. A. M. (2013). An integrated management systems approach to corporate social responsibility. Journal of Cleaner Production, 56, 7-17. https://doi.org/10.1016/j.jclepro.2011.10.034

Balachandran, V., \& Malani, H. (2013). An analysis of consumers' perceptions of corporate social responsibility with special reference to Karaikudi. International Journal of Management and Social Sciences Research, 2(1), 1-5.

Berman, S. L., Wicks, A. C., Kotha, S., \& Jones, T. M. (1999). Does stakeholder orientation 
matter? The relationship between stakeholder management models and firm financial performance. Academy of Management journal, 42(5), 488-506.

https://doi.org/10.2307/256972

Bhattacharya, C. B., \& Sen, S. (2004). Doing better at doing good: When, why, and how consumers respond to corporate social initiatives. California management review, 47(1), 9-24. https://doi.org/10.2307/41166284

Bisschop, L. (2010). Corporate environmental responsibility and criminology. Crime, law and social change, 53(4), 349-364. https://doi.org/10.1007/s10611-009-9227-8

Campbell, J. L. (2007). Why would corporations behave in socially responsible ways? An institutional theory of corporate social responsibility. Academy of Management Journal, 32(3), 946-967. https://doi.org/10.5465/amr.2007.25275684

Carrigan, M., \& Attalla, A. (2011). The Myth of the ethical Consumer - Do ethics matter in purchase behaviour?. Journal of Consumer Marketing, 18(7), 560-577.

https://doi.org/10.1108/07363760110410263

Carroll, A. B. (1991). The pyramid of corporate social responsibility: Toward the moral management of organizational stakeholders. Business Horizons, 34(4), 39-48.

https://doi.org/10.1016/0007-6813(91)90005-G

Cruz, J. M. (2013). Modeling the relationship of globalized supply chains and corporate social responsibility. Journal of Cleaner Production, 56, 73-85.

https://doi.org/10.1016/j.jclepro.2011.09.013

European Commission. 2001. Promoting a European framework for Corporate Social Responsibility, COM (2001) 366 final, 18.07.2001. EC: Brussels.

European Commission. 2011. A renewed EU strategy 2011-14 for Corporate Social Responsibility, COM (2011) 681 final, 25.10.2011. EC: Brussels.

Dögl, C. \& Behnam, M. (2014). Environmentally Sustainable Development through Stakeholder Engagement in Developed and Emerging Countries. Business Strategy and the Environment, 24(4), 583-600. https://doi.org/10.1002/bse.1839

Dummett, K. (2006). Drivers for corporate environmental responsibility (CER). Environment, Development and Sustainability, 8(3), 375-389. https://doi.org/10.1007/s10668-005-7900-3

Green, T., \& Peloza, J. (2014). How do consumers infer corporate social responsibility? The role of organisation size. Journal of Consumer Behaviour, An international Research Review, 13(4), 282-293. https://doi.org/10.1002/cb.1466

Grimmer, M., \& Bingham, T. (2013). Company environmental performance and consumer purchase intentions. Journal of Business Research, 66(10), 1945-1953. https://doi.org/10.1016/j.jbusres.2013.02.017

Groza, M. D., Pronschinske, M.R., \& Walker M. (2011). Perceived organizational motives and consumer responses to proactive and reactive CSR. Journal of Business Ethics, 102(4), 
639-652. https://doi.org/10.1007/s10551-011-0834-9

Gunningham, N. (2009). Shaping corporate environmental performance: a review. Environmental Policy and Governance, 19(4), 215-231.

https://doi.org/10.1002/eet.510

Gupta, M., \& Hodges, N. (2012). Corporate social responsibility in the apparel industry: An exploration of Indian consumers' perceptions and expectations. Journal of Fashion Marketing and Management: An International Journal, 16(2), 216-233.

https://doi.org/10.1108/13612021211222833

Kassinis, G., \& Vafeas, N. (2006). Stakeholder pressures and environmental performance. Academy of Management Journal, 49(1), 145-159.

https://doi.org/10.5465/AMJ.2006.20785799

Lee, K. H., \& Shin, D. (2010). Consumers' responses to CSR activities: The linkage between increased awareness and purchase intention. Public Relations Review, 36(2), 193-195. https://doi.org/10.1016/j.pubrev.2009.10.014

Lu, Y., \& Abeysekera, I. (2013). Stakeholders' power, corporate characteristics and social and environmental disclosure: evidence from China. Journal of Cleaner Production, 64, 426-436. https://doi.org/10.1016/j.jclepro.2013.10.005

Lu, W., Chau, K. W., Wang, H., \& Pan, W. (2014). A decade's debate on the nexus between corporate social and corporate financial performance: a critical review of empirical studies 2002-2011. Journal of Cleaner Production, 79, 195-206.

https://doi.org/10.1016/j.jclepro.2014.04.072

Luo, X., \& Bhattacharya, C. B. (2006). Corporate social responsibility, customer satisfaction, and market value. Journal of Marketing, 70(4), 1-18. https://doi.org/10.1509/jmkg.70.4.1

Maignan, I. (2001). Consumers' perceptions of corporate social responsibilities: A cross-cultural comparison. Journal of Business Ethics, 30(1), 57-72.

doi:10.1023/A:1006433928640

Marquina, P., \& Morales, C. E. (2012). The influence of CSR on purchasing behaviour in Peru and Spain. International Marketing Review, 29(3), 299-312. https://doi.org/10.1108/02651331211229778

Martí-Ballester, C. P. (2015). Can socially responsible investment for cleaner production the financial performance of Spanish pension plans?. Journal of Cleaner Production, 106, 466-477. https://doi.org/10.1016/j.jclepro.2014.06.058

Miles, M. B., \& Huberman, A. M. (1994). Qualitative data analysis: A sourcebook. Beverly Hills: Sage Publications.

Mohr, L. A., Webb, D. J., \& Harris, K. A. (2001). Do consumers expect companies to be socially responsible? The impact of corporate social responsibility on buying behaviour. Journal of Consumer Affairs, 35(1), 45-72. 
https://doi.org/10.1111/j.1745-6606.2001.tb00102.x

Montiel, I. (2008). Corporate social responsibility and corporate sustainability separate pasts, common futures. Organization \& Environment, 21(3), 245-269.

https://doi.org/10.1177/1086026608321329

Öberseder, M., Schlegelmilch, B. B., \& Murphy, P. E. (2013). CSR practices and consumer perceptions. Journal of Business Research, 66(10), 1839-1851.

https://doi.org/10.1016/j.jbusres.2013.02.005

O'Connor, M., \& Spangenberg, J. H. (2008). A methodology for CSR reporting: assuring a representative diversity of indicators across stakeholders, scales, sites and performance issues. Journal of Cleaner Production, 16(13), 1399-1415.

https://doi.org/10.1016/j.jclepro.2007.08.005

Papadopoulos, D., Dimitriadis, E., Chatzoudes, D., \& Andreadou, O. (2011). The impact of corporate social responsibility (CSR) policies on perceptions and behavioral intension of Greek consumers. Scientific Bulletin -Economic Sciences, 10(1), 93-102.

Rahim, R. A., Jalaludin, F. W., \& Tajuddin, K. (2011). The importance of corporate social responsibility on consumer behaviour in Malaysia. Asian Academy of Management Journal, 16(1), 119-139.

Rananger, H., \& Zobel, T. (2014). Revisiting the how of corporate social responsibility in extractive industries and forestry. Journal of Cleaner Production, 1-14.

https://doi.org/10.1016/j.jclepro.2014.02.020

SSchatzman, L., \& Strauss, A. L. (1973). Field research: Strategies for a natural sociology. Englewood Cliffs, N.J: Prentice-Hall.

Sen, S., \& Bhattacharya, C.B., (2001). Does doing good always lead to doing better? Consumer reactions to corporate social responsibility. Journal of Marketing Research, 38(2), 225-243. https://doi.org/10.1509/jmkr.38.2.225.18838

Sidiropoulos, E. (2013). Education for sustainability in business education programs: a question of value. Journal of Cleaner Production, 1-16.

https://doi.org/10.1016/j.jclepro.2013.10.040

Singh, J., de los Salmones Sanchez, M. M. G., \& del Bosque, I. R. (2008). Understanding corporate social responsibility and product perceptions in consumer markets: A cross-cultural evaluation. Journal of Business Ethics, 80(3), 597-611.

https://doi.org/10.1007/s10551-007-9457-6

Stanaland, A. J. S, Lwin, M. O., \& Murphy, P. E. (2011). Consumer perceptions of the antecedents and consequences of corporate social responsibility. Journal of Business Ethics, 102(1), 47-55. https://doi.org /10.1007/s10551-011-0904-z

Tian, Z., Wang, R., \& Wen, Y. (2011). Consumer responses to corporate social responsibility (CSR) in China. Journal of Business Ethics, 101(2), 197-212. 
https://doi.org/10.1007/s10551-010-0716-6

Welford, R., Chan, C., \& Man, M. (2008). Priorities for corporate social responsibility: a survey of businesses and their stakeholders. Corporate Social Responsibility and Environmental Management, 15(1), 52-62. doi:10.1002/csr.166

Wigley, S. (2008). Gauging consumers' responses to CSR activities: does increased awareness make cents?. Public Relations Review, 34(3), 306-308.

https://doi.org/10.1016/j.pubrev.2008.03.034

Youn, S., \& Kim, H. (2008). Antecedents of consumer attitudes toward cause-related marketing. Journal of Advertising Research, 48(1), 23-137.

https://doi.org/0.2501/S0021849908080136

\section{Appendix}

Appendix 1. Survey Questionnaire

Section A.: Demographic and economic characteristics

Q1. Your gender: Male [ ] Female [ ]

Q2. Your age: years old

Q3. Your education: Elementary [ ] Secondary [ ] Bachelor Degree [ ] Master/ PHD degree [ ]

Q4. Your family status: Married [ ] Other [ ]

Q5. Your monthly private income: $€$

Section B: Attitudes towards firms' CSR and CER actions.

"Corporate Social Responsibility (CSR) is a process for firms to integrate social, environmental, ethical and human rights concerns into their operations and core strategy" (European Commission, 2011, page 6)

"Corporate Environmental Responsibility (CER) is a process for firms to adopt practices that benefit the environment on a long-term basis or mitigate the adverse impact of businesses on the environment that go beyond those that companies are legally obliged to adopt. Examples of company practices include recycling programs, carbon emissions reduction programs, programs for waste management, auditing, green technologies, etc." (Mazurkiewicz, 2004; Gunningham, 2009, 215)

Q6. Are you aware of companies in Greece that engage in CSR activities?

$$
\text { Yes [ ] No [ ] }
$$

Q7. If yes, please name one:

Q8. Have you ever sought information on a company's CSR actions?

$$
\text { Yes [ ] No [ ] }
$$

Q9. Are you aware of companies in Greece that adopt CER activities? 
Yes [] No []

Q10. If yes, please name one:

Q11. Do you think that companies should adopt CER activities to minimize the environmental damage they cause?

Yes [ ] No []

Q12. Do you usually participate in environmental friendly actions (such as recycling, waste management, eco-driving, reforestation, energy saving, etc.)?

$$
\text { Yes [ ] No [ ] }
$$

Thank you for finishing the survey.

\section{Copyright Disclaimer}

Copyright for this article is retained by the author(s), with first publication rights granted to the journal.

This is an open-access article distributed under the terms and conditions of the Creative Commons Attribution license (http://creativecommons.org/licenses/by/3.0/). 